\title{
Watershed Times for the Caddo Peoples of the Far Southeast
}

Timothy K. Perttula

Heritage Research Center, Stephen F. Austin State University

Follow this and additional works at: https://scholarworks.sfasu.edu/ita

Part of the American Material Culture Commons, Archaeological Anthropology Commons, Environmental Studies Commons, Other American Studies Commons, Other Arts and Humanities Commons, Other History of Art, Architecture, and Archaeology Commons, and the United States History Commons

Tell us how this article helped you.

This Article is brought to you for free and open access by the Center for Regional Heritage Research at SFA ScholarWorks. It has been accepted for inclusion in Index of Texas Archaeology: Open Access Gray Literature from the Lone Star State by an authorized editor of SFA ScholarWorks. For more information, please contact cdsscholarworks@sfasu.edu. 


\section{Watershed Times for the Caddo Peoples of the Far Southeast}

Creative Commons License

(c) (i) (8)

This work is licensed under a Creative Commons Attribution-NonCommercial 4.0 International License 


\title{
Watershed Times for the Caddo Peoples of THE FAR SOUTHEAST
}

\author{
Timothy K. Perttula
}

\section{Introduction}

A.D. 1450 was a watershed year in the native history of the Caddo Indian peoples of the Far Southeast (southwest Arkansas, northwest Louisiana, eastern Oklahoma, and eastern Texas). For the first time, recognizable and relatively geographically coherent socio-political polities in several areas can be identified that arose out of the distinctive archaeological traditions of the Caddo area that first are recognizable about A.D. 900. These new Caddo polities that came into existence at ca. A.D. 1450 apparently lasted until at least A.D. 1680, if not later, but did not survive sustained European contact with the same socio-political organization intact that they started with in those watershed times.

This dynamic development among Caddo peoples occurred in tandem with a more uniform intensification of maize agriculture in prime Far Southeast habitats after ca. A.D. 1300, extensive intra-areal movements of Caddo groups in combination with the abandonment of agriculturally marginal regions, possible new religious developments heralded by indirect archaeological evidence for the use of peyote and other psychotropic drugs among some East Texas Caddo peoples after ca. A.D. 1430, and widespread trade and exchange with indigenous Southern Plains and Southeastern cultures. The introduction of epidemic diseases by the early 1690s, along with slave raiding from tribes east of the Mississippi River (see Ethridge 2009), took a terrible toll on the Caddo peoples in the years to come, but the dissolution of several pre-contact Caddo sociopolitical polities, and the transformation of them into new Caddo cultural identities, did not occur until well into the $18^{\text {th }}$ century, about 1730 .

Looking past the period of protohistory-the time between prehistory and history when few written records are available, and for which most evidence about Caddo peoples must be derived from archaeology (cf. Perttula 2002) - to the time when there are detailed written records regularly compiled by Europeans about the Caddo people, beginning ca. 1686 and after (and thus not including the De Soto chronicles from the early 1540s), what was the Caddo landscape like? For Europeans, the Caddo were the center piece in the Far Southeast (Figure 1). They were the preeminent tribe in the Far Southeast, and all roads, trails, and trade led through the Caddo, particularly the trade in horses and guns.

Archaeologists working in what Krieger (2009) termed the "so-called Caddo area," recognized early on the unique geographic position of the Caddo betwixt the Southwest and the Southeast (Figure 2). It was clear that the Caddo were the most socially and politically complex aboriginal population on the far reaches of the Southeast, a position that they maintained for hundreds of years, and likely would have maintained for hundreds of years more if Europeans had not embarked on the conquest and conversion of Native peoples. 







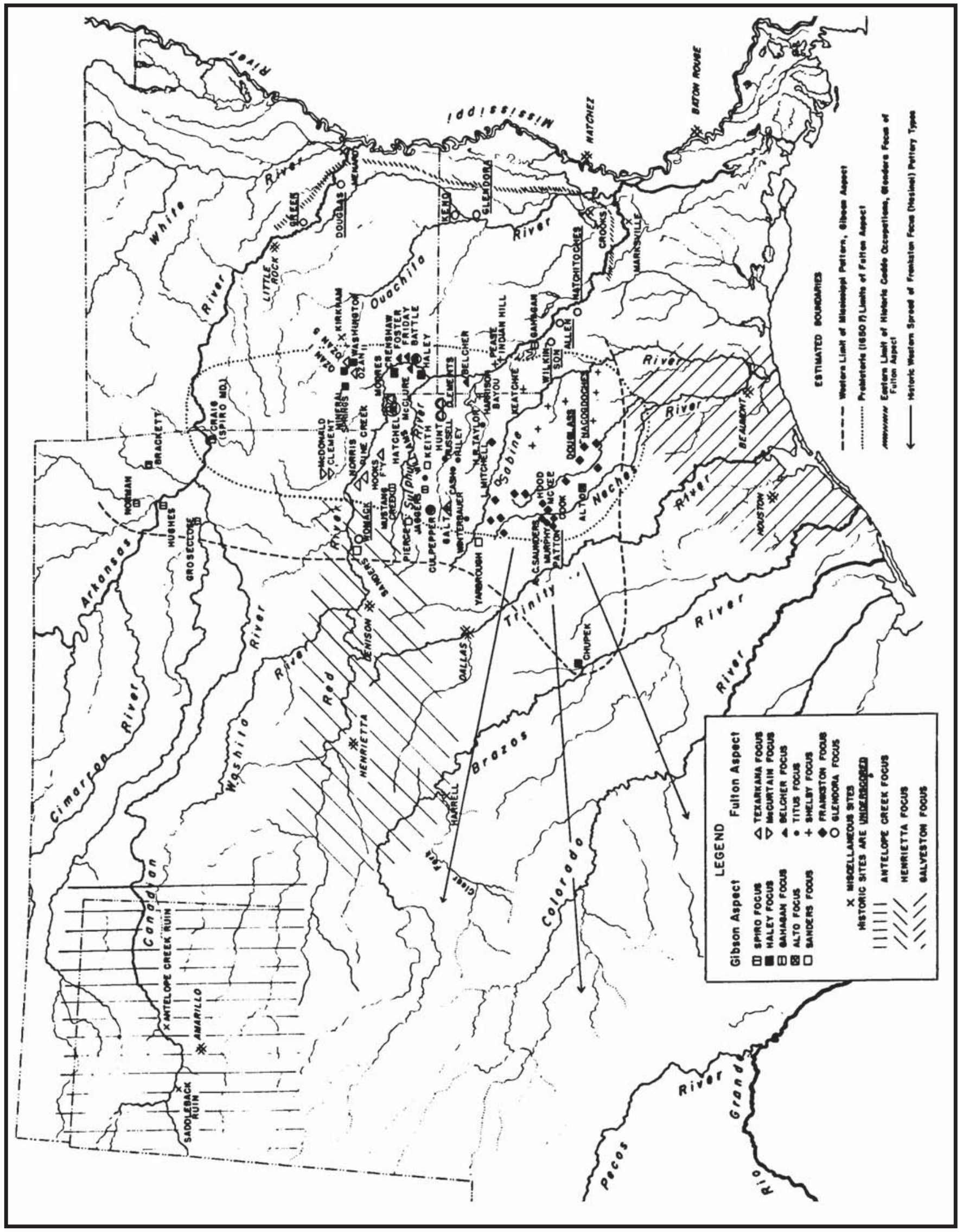


The Caddo were virtually unchallenged in their world. They had no fortified settlements, and little evidence for warfare or conflict (notwithstanding the skull and mandible caches at the Crenshaw site, Schambach 1996) is apparent in the archaeological record. This likely speaks to the fact that the Caddo had little to fear from their neighbors (primarily hunter-gatherer foragers) and little need for strong defenses (cf. Dye 2009:12).

Ethnographic information on the location of Caddo groups show that much of the Caddo world was emptied by the early $18^{\text {th }}$ century, perhaps as early as the 1690 s (Figure 3 ). By this time, the Caddo were no longer unchallenged.

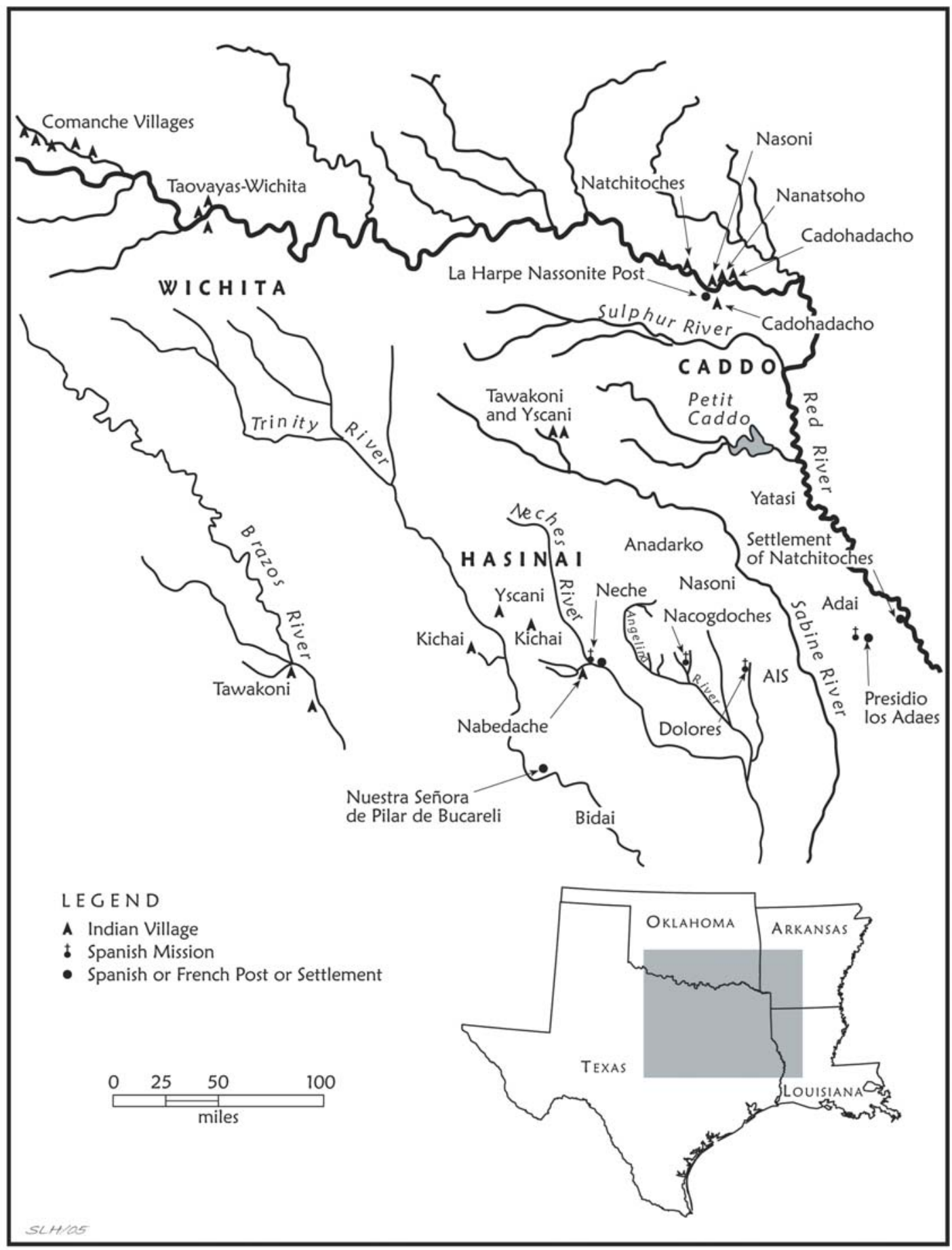

Figure 3. Ethnographically recorded locations of Caddo groups, ca. early $18^{\text {th }}$ to mid- $18^{\text {th }}$ century. 


\section{Caddo Communities and Complexity: The $15^{\text {th }}$ Century A.D. to the Time of more Continuous Contact with Europeans in the Late $17^{\text {th }}$ Century A.D.}

The archaeological view of the ca. A.D. 1400-1680 period indicates that Caddo groups of varying sizes, complexity, and local history were widely distributed across both major and minor streams in the area (Figure 4). Subtle population and territorial readjustments, coupled with continued mound building in some major valleys, trade activities (salt and bow wood), and other pursuits suggests these were prosperous farmers with sustainable social and political structures.



Figure 4. The distribution of Late Caddo (ca. A.D. 1400-1680) phases in the Caddo area. In the Mid-Ouachita region, this would include the temporally Mid-Ouachita, Social Hill, and Deceiper phases (Early 1993). 
As already mentioned above, A.D. 1450 was a watershed year for the Caddo peoples, as indeed it was in parts of the Southwest (Lekson 2009:249), the Vacant quarter area (Cobb and Butler 2002) in the MississippiOhio rivers area, and the southern Plains (see Perkins and Baugh 2008). This time is one of those "hinge points" discussed by Lekson, a "time of change." Paleoclimatic evidence may hold part of the key to understanding this time of change and I think that droughts helped shape Caddo history. Paleoclimatic data from tree rings indicate that very dry years were quite rare between A.D. 1000-1400, but after that time dry years were more common (Figure 5). The driest and coolest years during the Caddo occupation of East Texas and surrounding states occurred in the major drought years of ca. A.D. 1430-1470 (especially A.D. 1444-1447 and 1455-1460).
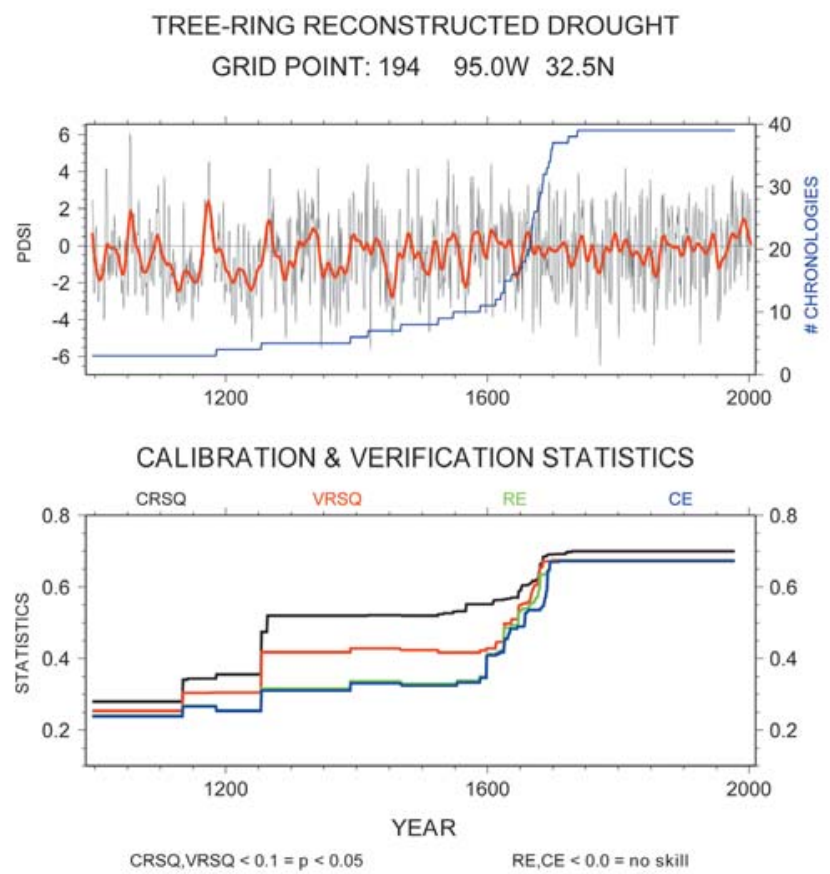

Figure 5. Tree-ring reconstructed droughts in the Texarkana area, Red River, A.D. 1000-2000. From North American Drought Atlas: A History of Meteorological Drought Reconstructed from 835 Tree-Ring Chronologies for the past 2005 years. Lamont-Doherty Earth Observatory and Tree-Ring Lab.

The period from ca. A.D. 14301470 was apparently the coolest (Figure 6) and driest in the last 1000 years in the general region. For farmers with agricultural economies, this was more than some Caddo polities could survive. Is it a coincidence that these climatically challenging years occurred at the same time as some fundamental changes in Caddo society along with evidence of abandonment and population movements? I do not happen to think that is the case.

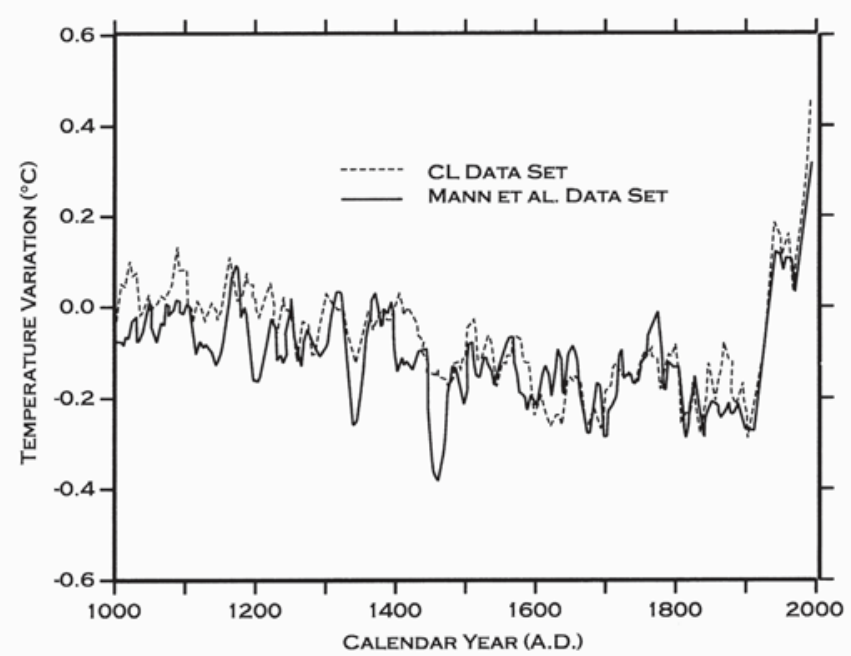

Figure 6. Temperature variation, A.D. 1000-2000. Note significant cooling ca. A.D. 1450-1470 (Perttula 2008:Figure 2). 
Archaeological data on the density and distribution of settlements after ca. A.D. 1450 (Figure 7) point to the regional abandonment of several parts of the Caddo area at and around that time, including much of the Ouachita Mountains and Caddo settlements in particularly drought-prone areas along the western margins of Caddo territory (upper Sabine, upper Neches, and upper Sulphur in East Texas, certainly; Blackland Prairie areas in southwestern Arkansas, Lockhart 2007). These areas may have been marginally suitable for the successful cultivation of maize. One related product of this regional abandonment may have been the consolidation of Caddo societies into areas or habitats that were perceived by their political leaders as most suitable to maintain economies dependent upon agricultural crops for subsistence.

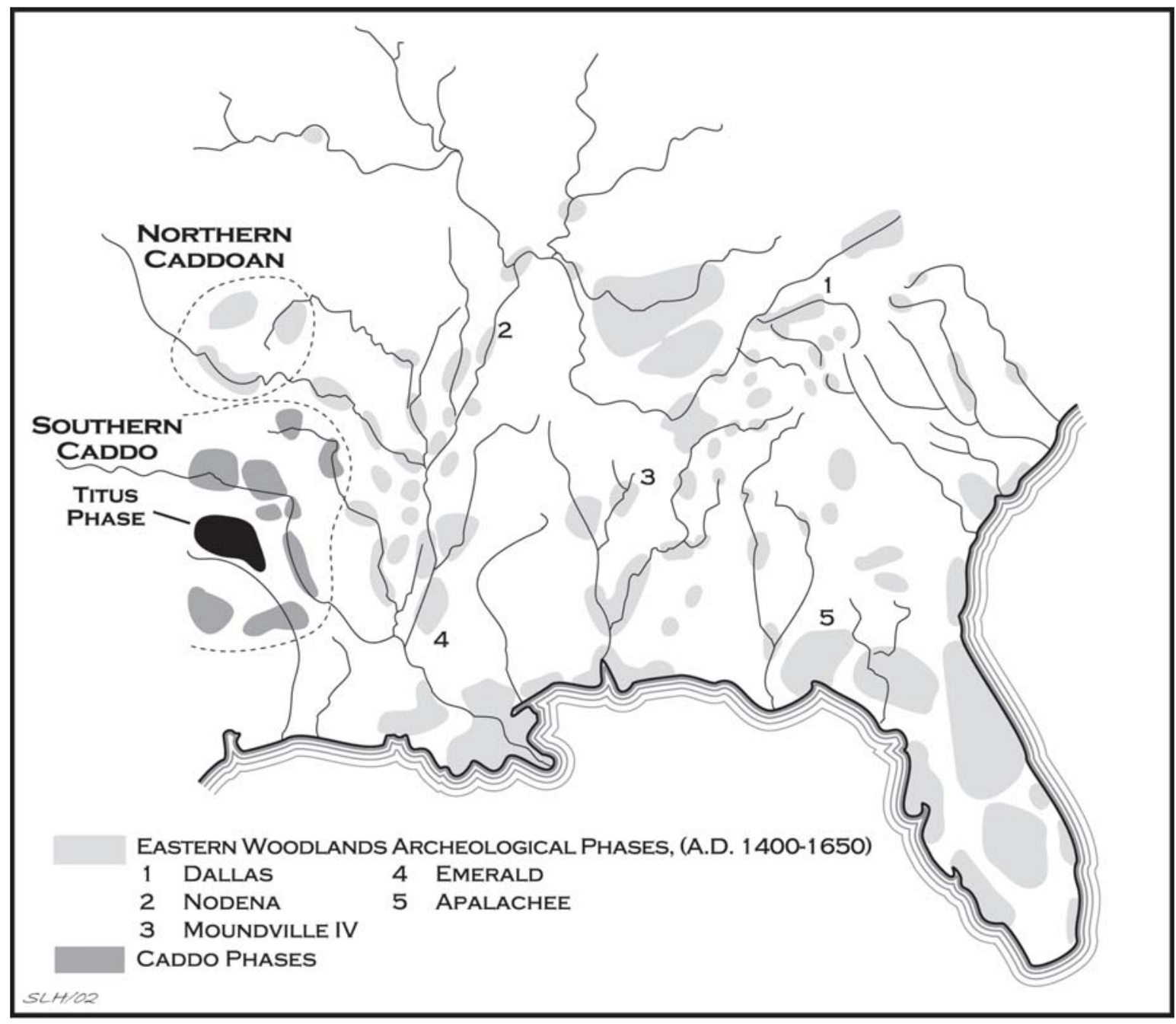

Figure 7. Caddo groups and phases at the Far Southeast, post- $15^{\text {th }}$ century A.D.

Once this consolidation took place, these Caddo polities remained anchored to these lands until at least ca. the 1680s along the Red River and East Texas, as well as parts of the mid-Ouachita region. To the north, Rogers (2006) suggests Fort Coffee phase Northern "Caddoan" groups remained in the Arkansas River basin until ca. 1660 .

What were these $15^{\text {th }}-17^{\text {th }}$ century Caddo polities like? A few examples from East Texas and southwest Arkansas should suffice to illustrate their social and political complexity prior to sustained European contact. Other examples from northwest Louisiana (Webb 1959) and the mid-Ouachita River basin (Early 1993) also come readily to mind. 
First, the preponderance of archaeological evidence from the political communities recognized in the Titus phase area of East Texas (Figure 8) clearly demonstrate that powerful and populous Caddo groups lived in this area through much of the $17^{\text {th }}$ century. Seriation analysis of ceramic vessels and arrow point styles from Titus phase burials and cemetery sites suggests that the large and well-planned community cemeteries (with 50-200+ individuals in each, and used for multiple generations) date after the early $16^{\text {th }}$ century and were in use until at least the early to mid-1 $7^{\text {th }}$ century (Perttula 2005:387-388). Dates from constructed mounds, either platform or substructural, indicate the same temporal range for their use.

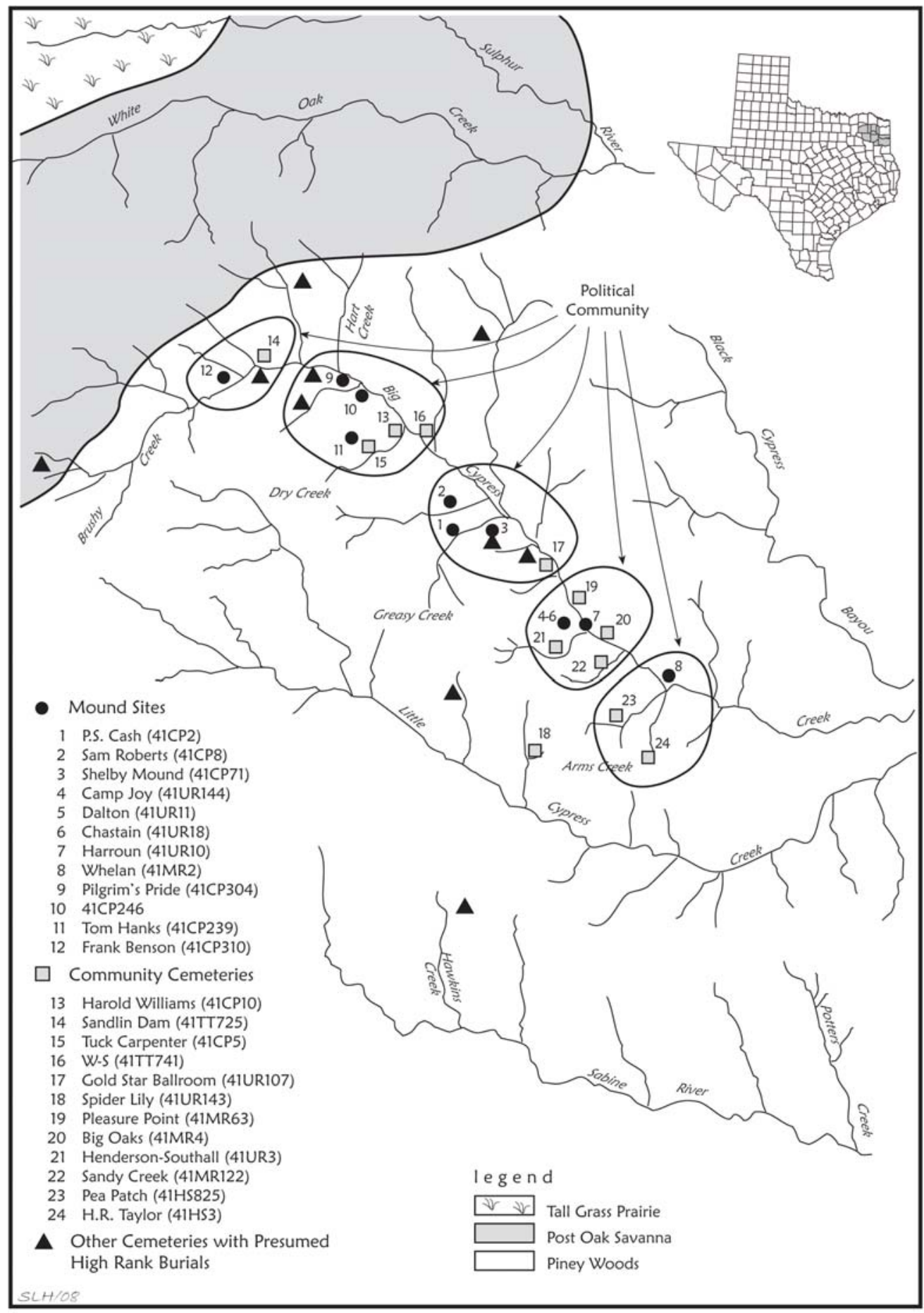

Figure 8. Titus phase political communities in the Big Cypress Creek basin. Note post-A.D. 1450 mound sites. 
The Shelby Mound site (41CP71) on Greasy Creek in the Big Cypress Creek basin is one of the more important Titus phase sites because of its large and well-preserved settlement with abundant habitation features, evidence of mound building activities, and a large community cemetery with at least 119 burial pits (Figure 9) and perhaps as many as 200.

One Caddo individual buried there (Burial 117), probably an adult male, appears to have been a socially important person, since he was buried resting on a cedar pole litter. This person appears to have then been buried in a tomb (accompanied by many decorated pottery vessels as well as caches of expertly knapped Talco arrow points) placed below the floor of a structure, after which the structure was burned, capping the tomb (Perttula 2005:382), and leaving a large deposit of daub overlying the burial.

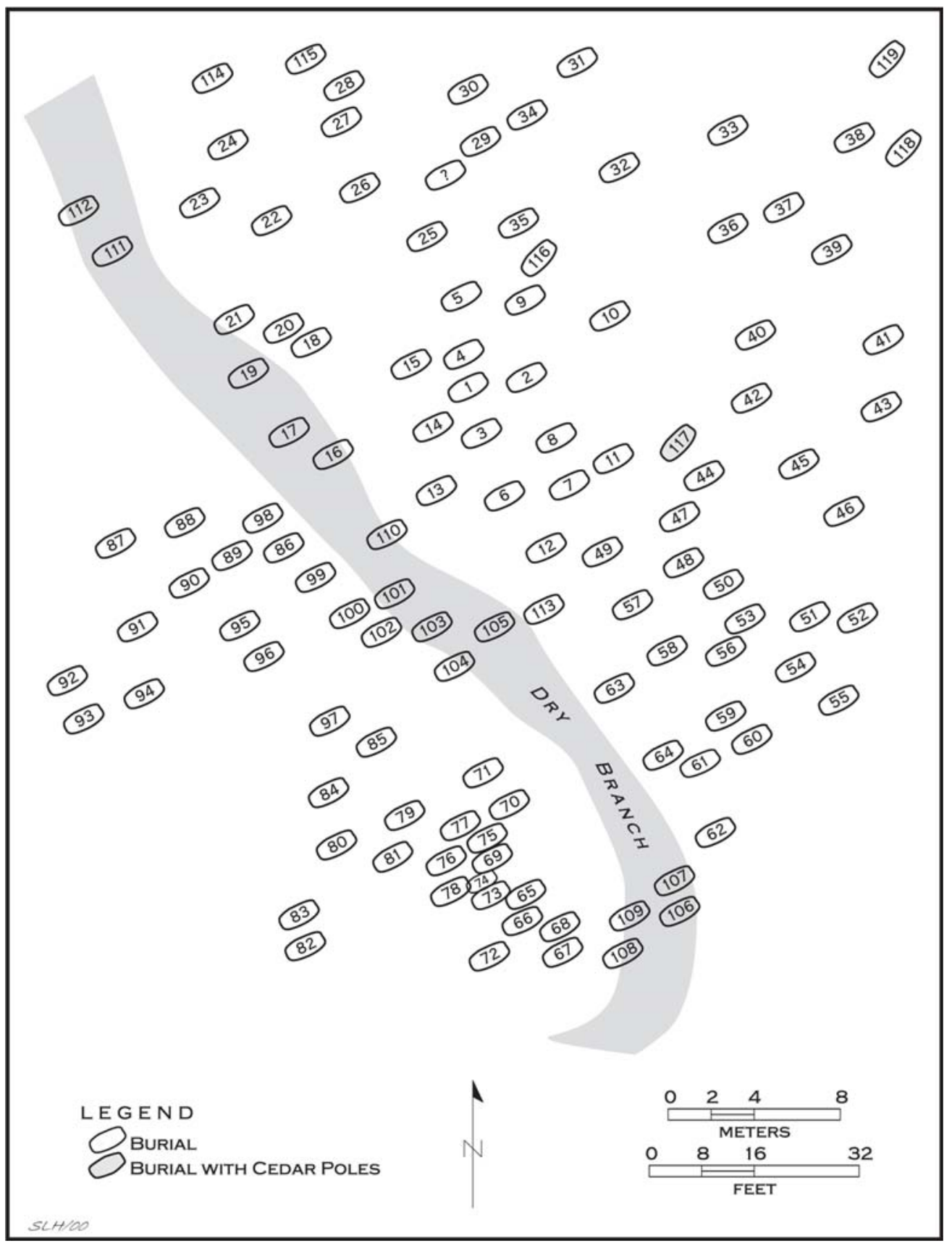

Figure 9. Late Caddo community cemetery at the Shelby site (41CP71). 
No other Caddo litter burials are known from East Texas mortuary contexts in post-A.D. 1430 times, which certainly points to the social significance of this Caddo individual. At a certain level, it compares with a number of cedar pole litter burials from individuals with a "superior social standing" (accompanied by a truly unique assortment of grave goods) that have been documented in $14^{\text {th }}$ century A.D. burials in the Special Mortuary of the Craig Mound at the Spiro site in the Arkansas River valley in eastern Oklahoma (Brown 1996:85103).

I obtained a radiocarbon date on one of the cedar poles from the Shelby site: at 2 sigma, the calibrated age range is $\mathrm{AD} 1430-1640$, with a calibrated intercept of $\mathrm{AD} 1470$. Considered in context with the radiocarbon dates from mound and habitation features, the burial litter at the Shelby site may well have been interred in the large community cemetery in the latter part of the $15^{\text {th }}$ and the first part of the $16^{\text {th }}$ century A.D. To reiterate, the 2 sigma calibrated radiocarbon age range from the litter burial points to the burial of a socially superior Caddo individual in a ranked Titus phase political community sometime after the early part of the $16^{\text {th }}$ century A.D. There clearly is no diminution in social complexity at the cusp of European contact.

Further evidence of Caddo social complexity in the protohistoric period is the archaeological evidence from the Hatchel site (41BW3) on the Red River in the northeastern corner of what is now Texas. The Hatchel site (Figure 10) is one of the most significant prehistoric and early historic Caddo Indian sites in the state. The modern Caddo people, although they have not lived at the site in more than 300 years, still feel a connection to this place (Perttula et al. 2008:102).

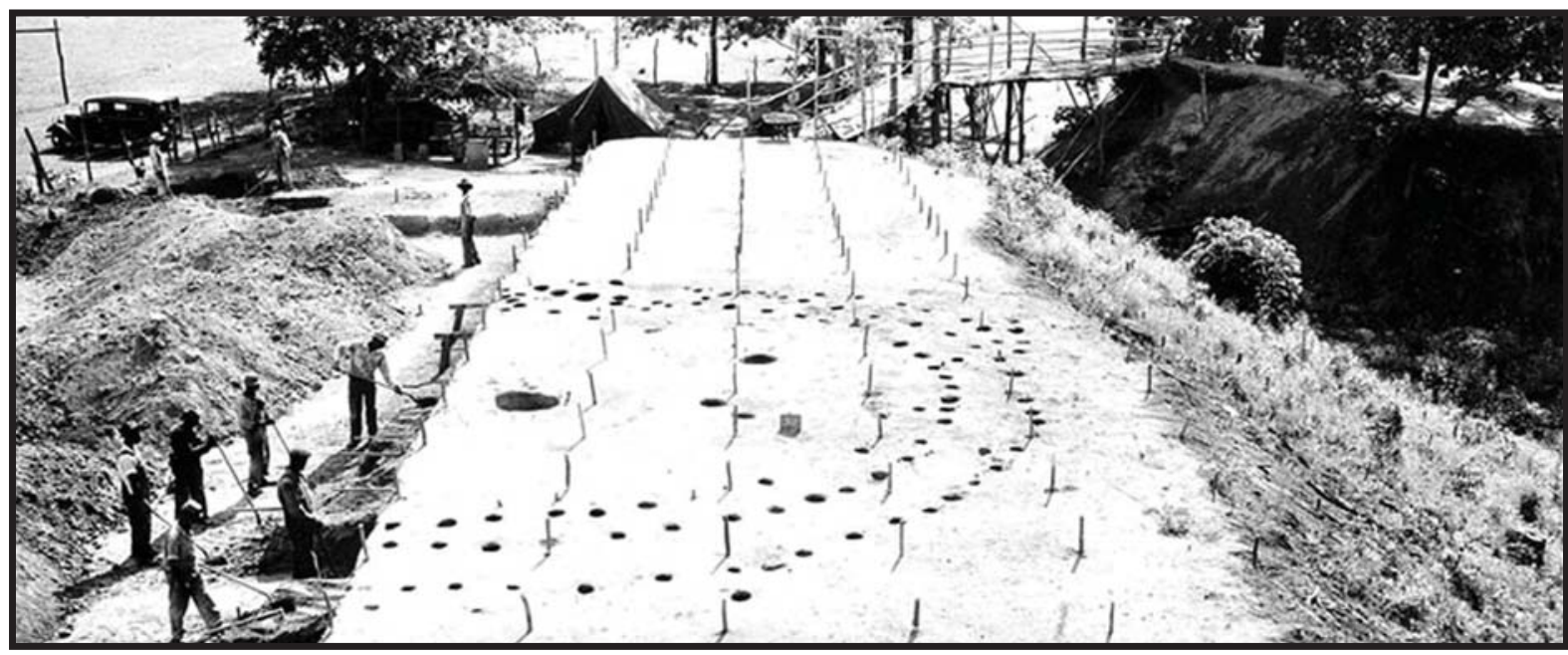

Figure 10. 1938-1939 WPA excavations in Late Caddo mound at the Hatchel site on Red River.

The Hatchel site contains at least five mounds, including one primary platform mound that stood $30 \mathrm{ft}$. high, along with extensive village and cemetery areas covering several hundred acres. The site was one of the premier Caddo civic and ceremonial centers along the Red River from as early as ca. A.D. 1100 until the early $18^{\text {th }}$ century. Works Progress Administration excavations of the platform mound in the late 1930s disclosed that it had a ca. A.D. $1200-1400$ core overlain by a massive $15^{\text {th }}$ through $17^{\text {th }}$ century platform with seven stages of construction and use; there are at least 16 important circular Caddo structures (many deliberately burned) on these stages. When the Don Domingo Teran de los Rios expedition visited the site in 1691, the templo or temple mound at the Hatchel site was still in use (Wedel 1978:Figure 2). There clearly was no vacuum in Caddo social and political power at this time and place. 
Lastly, the Battle Mound (3LA1) is the largest known Caddo mound-205 $\mathrm{m}$ in length, $98 \mathrm{~m}$ in width, and $10.4 \mathrm{~m}$ high (Figure 11) - and one of the largest platform mounds in the southeastern United States (Muller 1978:321). It was built primarily in post-A.D. 1500 Belcher phase times over a low (1.8 m) Haley phase mound platform (see McKinnon 2010a, 2010b). During the Belcher phase, it was here in the Great Bend region that the Caddo cultural tradition reached its peak in population and socio-political complexity (Perttula 1992:24; Schambach 1989:20). By the early $18^{\text {th }}$ century, however, there were only dispersed Caddo farmstead compounds on Chicaninna Prairie.

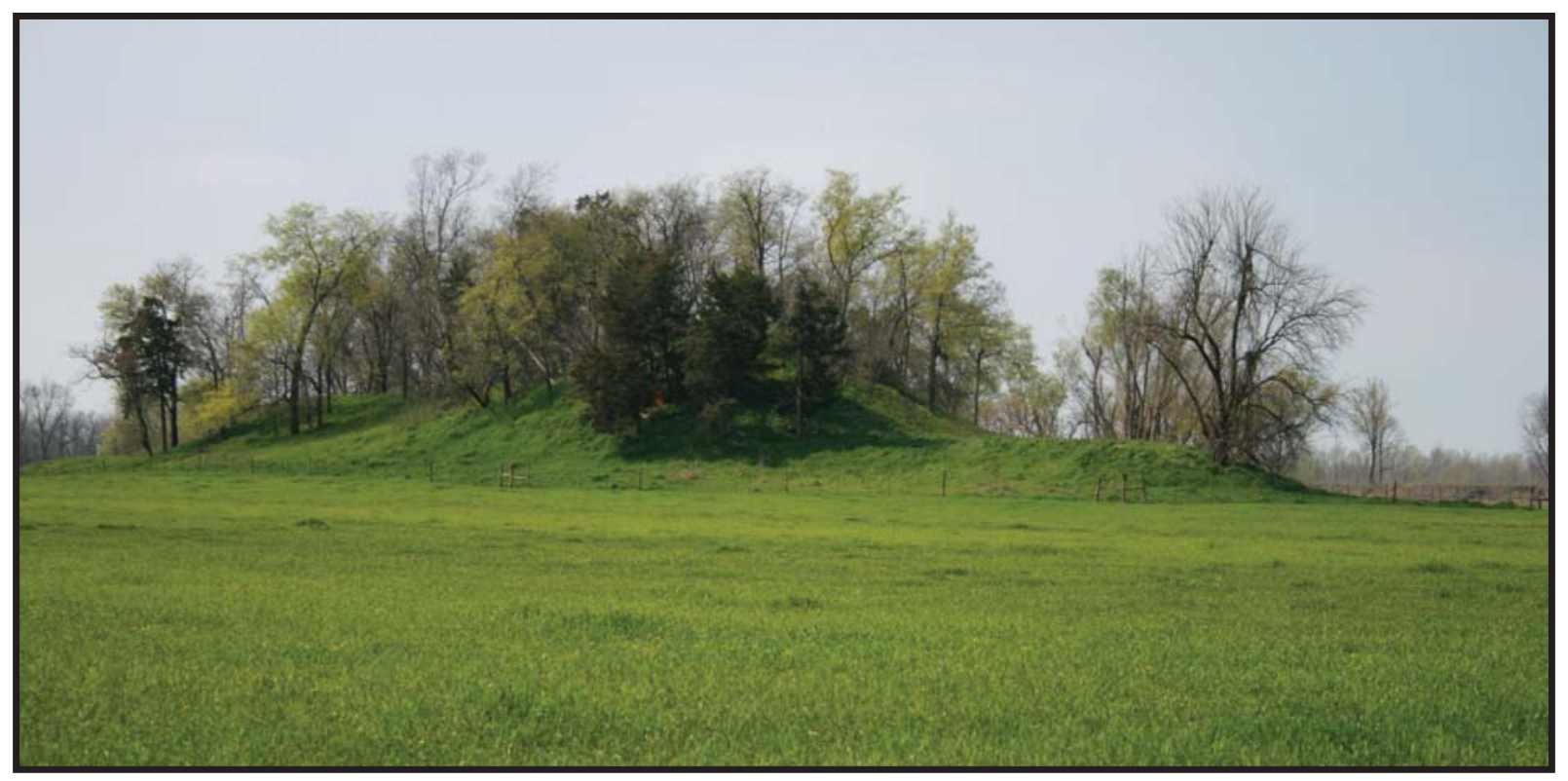

Figure 11. Battle site on the Red River in the Great Bend area. This is the largest, and primarily Late Caddo constructed, mound site on Red River.

By the early $18^{\text {th }}$ century, the distribution of Historic Caddo sites points to the fact that there certainly had been demographic changes, and a regional winnowing of Caddo populations and occupied archaeological sites (Figure 12). Much, if not all, of southwestern Arkansas and southeastern Oklahoma was bereft of people, and some Caddo tribes had already moved to amalgamate with others, as in the case of the Cahinnio who had moved from the Ouachita to the Red River. Caddo polities remained in East Texas, especially in the Hasinai Caddo homelands in the Neches-Angelina river basins.

As attested to by the De Soto chronicles, just 150 years before, the Battle site was the likely the central site of the Naguatex province (Figure 13), almost certainly the most important and populous Caddo province in the mid-16 $6^{\text {th }}$ century (Hudson 1997). By the early $18^{\text {th }}$ century, the area was home to scattered villages (see Figure 12).

La Salle's expeditions into the Caddo area of East Texas in 1686-1687 effectively bring the protohistoric period to an end in the Far Southeast homelands of the Caddo peoples. At that time, the Spanish already referred to the East Texas Caddo as the "Great Kingdom of the Tejas," and they were still a populous nation. One Spanish chronicler in 1690 noted that their principal settlement "encompasses fourteen to fifteen leagues [35-40 miles], but we were unable to see all of it ... In the part we did see there were more than four thousand people" (Perttula 2002:262). 


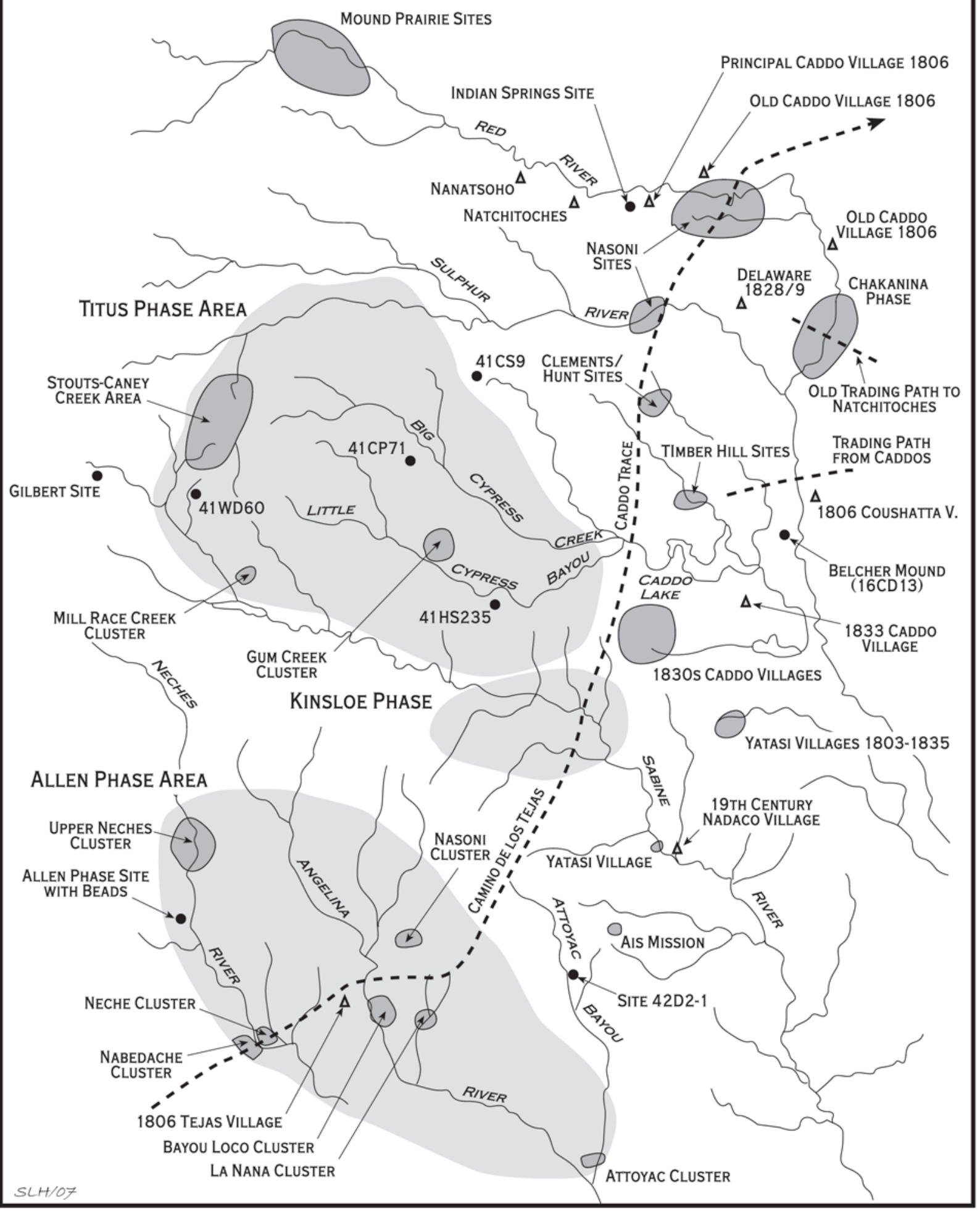

Figure 12. The dissolution of the Caddo? Historic Caddo sites and phases. 


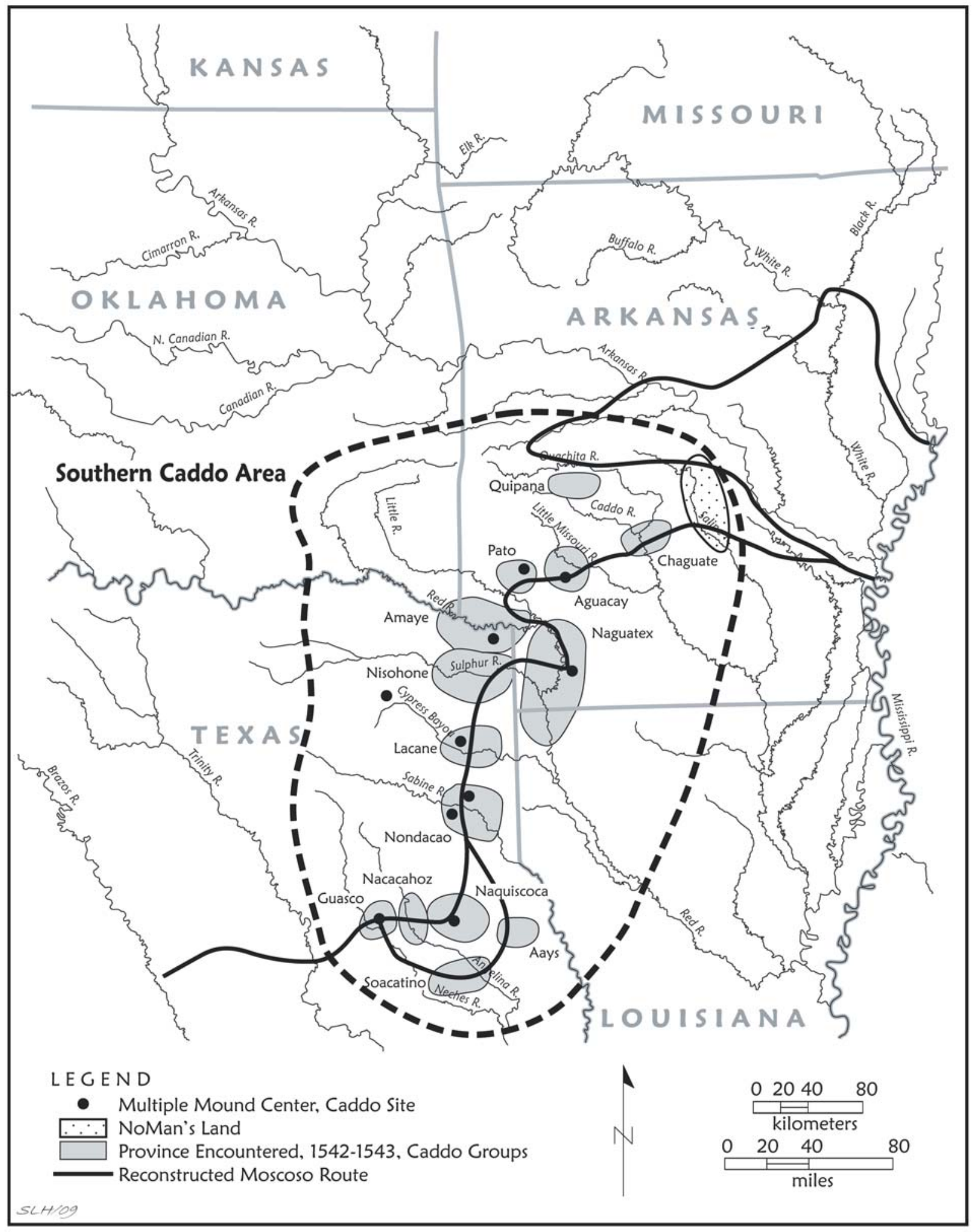

Figure 13. De Soto's 1542 entrada: probable path through Caddo country. 


\section{Summary}

- What was the nature of Caddo culture prior to European contact with respect to demographic, economic, socio-political, and religious developments during the period from ca. A.D. 1450-1650?

The culture of the Caddo peoples between ca. A.D. 1450-1650 was diverse with respect to demography, economy, as well as socio-political and religious developments. There were distinctions between rural and town communities, the latter concentrated in the major river valleys, and having higher population densities than those communities away from the major rivers. The Caddo by this time were agriculturists, in the midst of an intensification in agriculture that led to abandonment of some areas and a concentration of peoples in other areas. These population clusters had centers where the social and political elite lived, and these centers had platform mounds or mounds that covered the burned structures of the elites. Religious ceremonies and rituals were likely concentrated at the centers, a number of which were still occupied well into the $17^{\text {th }}$ century. Representation of peyote buttons on post-A.D. 1430 Titus phase ceramic vessels suggest the development or elaboration of powerful rituals and ceremonies designed to allow the elites and the people to better communicate with the spirits and the Caddi Ayo.

- Is there evidence in the archaeological record for either indirect and direct responses by the Caddo in protohistoric times to the European presence in the Far Southeast?

This question is more difficult to answer because of the meager archaeological record relevant to Caddo-European contact. Bioarchaeological investigations recently completed in the upper Neches River basin in East Texas have shown that (a) there is a significant decrease (about 20\%) in the average age of death from Late Caddo to Historic Caddo times, after ca. 1680; (b) there are significant increases in evidence for enamel hypoplasias and childhood iron deficient anemia (cribra orbitalia). This is the only incidence of cribra orbitalia in the entire ca. A.D. 900-1700+ Upper Neches population. The incidence of enamel hypoplasia and cribra orbitalia suggest a high incidence of childhood stress among the Caddo in historic times; and (c) other pathological signs of nutritional stress (porotic hyperostosis) are common only in the historic Caddo remains (Wilson 2011a, 2011b).

It does appear to be the case that Caddo living in the late $17^{\text {th }}$-early $18^{\text {th }}$ century in the upper Neches were in poor health, and this was probably associated with cultural stress, an increased population density (but not necessarily a larger number of people, as assumed from number of burials), and malnutrition. At this time maize intake was at its highest. Infection rates in the upper Neches show a steady increase up to the late $17^{\text {th }}$ century, when there is a dramatic decrease. It is possible that epidemic diseases were causing death prior to local endemic infections (Wilson 2011a, 2011b).

It has been seemingly well established that epidemics introduced by Europeans greatly reduced Caddo populations as much as $75-90 \%$ between 1691-1816; the same demographic catastrophe took place then in the Southeast (Ethridge 2009; Kelton 2007). I once thought that population losses among the Caddo were likely also significant in the period between ca. 1530-1691 (Perttula 2002:255), but with continued archaeological investigations (accompanied by the better dating of sites), and further consideration, I am now far from convinced that there were protohistoric population declines of much consequence. If there were significant responses of the Caddo groups to a European presence prior to ca. 1691, however slight it might have been (at least with respect to direct contact), I would look to the adoption of the horse and the gun, and the consequent remaking of Caddo trade, economic, and war-peace relationships with groups from the Southwest to the lower Mississippi River and beyond. 


\section{References Cited}

Brown, James A.

1996 The Spiro Ceremonial Center: The Archaeology of Arkansas Valley Caddoan Culture in Eastern Oklahoma. 2 Vols. Memoirs No. 29. Museum of Anthropology, University of Michigan, Ann Arbor.

Cobb, Charles R. and Brian M. Butler

2002 The Vacant Quarter Revisited: Late Mississippian Abandonment of the Lower Ohio Valley. American Antiquity 67:625-641.

Dye, David H.

2009 War Paths, Peace Paths: An Archaeology of Cooperation and Conflict in Native Eastern North America. AltaMira Press, Lanham, Maryland.

Early, Ann M. (editor)

1993 Caddoan Saltmakers in the Ouachita Valley: The Hardman Site. Research Series 43. Arkansas Archeological Survey, Fayetteville.

Ethridge, Robbie

2009 Introduction: Mapping the Mississippian Shatter Zone. In Mapping the Mississippian Shatter Zone: The Colonial Indian Slave Trade and Regional Instability in the American South, edited by Robbie Ethridge and Sheri M. Shuck-Hall, pp. 1-62. University of Nebraska Press, Lincoln.

Hudson, Charles M.

1997 Knights of Spain, Warriors of the Sun: Hernando de Soto and the South's Ancient Chiefdoms. University of Georgia Press, Athens.

Kelton, Paul

2007 Epidemics \& Enslavement: Biological Catastrophe in the Native Southeast, 1492-1715. University of Nebraska Press, Lincoln.

Krieger, Alex D.

2009 Archaeological Horizons in the So-Called Caddo Area. Archival Series 3. Texas Archeological Research Laboratory, The University of Texas at Austin.

Lekson, Stephen H.

2009 A History of the Ancient Southwest. School for Advanced Research Press, Santa Fe.

Lockhart, Jami J.

2007 Prehistoric Caddo of Arkansas: A Multiscalar Examination of Past Cultural Landscapes. Ph.D. dissertation, Department of Anthropology, University of Arkansas, Fayetteville.

McKinnon, Duncan P.

2010a Summer 1948: A Summary of Excavations at Battle Mound (3LA1), A Premier Caddo Mound Site in the Great Bend Region of the Red River. The Arkansas Archeologist 49:1-16.

2010b Continuing the Research: Archaeogeophysical Investigations at the Battle Mound Site (3LA1) in Lafayette County, Arkansas. Southeastern Archaeology 29(2):250-260. 


\section{References Cited (cont.)}

Muller, Jon D.

1978 The Southeast. In Ancient Native Americans, edited by Jesse D. Jennings, pp. 281-325. W. H. Freeman, San Francisco.

Perkins, Stephen M. and Timothy G. Baugh

2008 Protohistory and the Wichita. In "Lands of Our Ancestors: Studies in Protohistoric and Historic Wichita Cultures," edited by Timothy G. Baugh and Stephen M. Perkins, pp. 381-394. Memoir 40, Plains Anthropologist 53(208).

Perttula, Timothy K.

1992 "The Caddo Nation": Archaeological \& Ethnohistoric Perspectives. University of Texas Press, Austin.

2002 Social Changes among the Caddo Indians in the Sixteenth and Seventeenth Centuries. In The Transformation of the Southeastern Indians, 1540-1760, edited by Robbie Ethridge and Charles Hudson, pp. 249-269. University Press of Mississippi, Jackson.

2008 Caddo Agriculture on the Western Frontier of the Eastern Woodlands. Plains Anthropologist 53(205):79-105.

Perttula, Timothy K. (editor)

2005 Archeological Investigations at the Pilgrim's Pride Site (41CP304), a Titus Phase Community in the Big Cypress Creek Basin, Camp County, Texas. 2 Vols. Report of Investigations No. 30. Archeological \& Environmental Consultants, LLC, Austin.

Perttula, Timothy K., Dayna Bowker Lee, and Robert Cast

2008 The First People of the Red River: The Caddo Before and After Freeman and Custis. In Freeman and Custis Red River Expedition of 1806: Two Hundred Years Later, edited by Laurence M. Hardy, pp. 81-110. Bulletin of the Museum of Life Sciences No. 14. Museum of Life Sciences, Louisiana State University in Shreveport.

Rogers, J. Daniel

2006 Chronology and the Demise of Chiefdoms: Eastern Oklahoma in the Sixteenth and Seventeenth Centuries. Southeastern Archaeology 25(1):20-28.

Schambach, Frank F.

1989 The End of the Trail: The route of Hernando De Soto's army through southwest Arkansas and East Texas. The Arkansas Archeologist 27/28:9-33.

1996 Mounds, Embankments, and Ceremonialism in the Trans-Mississippi South. In Mounds, Embankments, and Ceremonialism in the Midsouth, edited by Robert C. Mainfort and Richard Walling, pp. 36-43. Research Series No. 46. Arkansas Archeological Survey, Fayetteville.

Webb, Clarence $\mathrm{H}$.

1959 The Belcher Mound: A Stratified Caddoan Site in Caddo Parish, Louisiana. Memoirs No. 16. Society for American Archaeology, Salt Lake City. 


\section{References Cited (cont.)}

Wedel, Mildred M.

1978 La Harpe's 1719 Post on Red River and Nearby Caddo Settlements. Bulletin 30. Texas Memorial Museum, Austin.

Wilson, Diane E.

2011a Bioarchaeological Evidence of Subsistence Strategies among the East Texas Caddo. In The Archaeology of the Caddo, edited by T. K. Perttula and C. P. Walker. University of Nebraska Press, Lincoln, in press.

2011b Analysis of Human Remains from the Lang Pasture Site. In Archeological Investigations at the Lang Pasture Site (41AN38) in the Upper Neches River Basin of East Texas, assembled and edited by T. K. Perttula, D. B. Kelley, and R. A. Ricklis, pp. 381-401. Report No. 129. Archeological Studies Program, Environmental Affairs Division, Texas Department of Transportation, Austin. 